\title{
Mohs' kirurgi ved basalcellekarsinom i ansiktet
}

\begin{abstract}
Sammendrag
Bakgrunn. Basalcellekarsinom kan ha et lokalt aggressivt vekstmønster. Denne hudkrefttypen sitter ofte i ansiktet og er vanskelig å avgrense klinisk. Vanlig eksisjon og tumordestruktive behandlingsmetoder fører ofte til tumorresidiv. Mohs' kirurgi er en operasjonsteknikk som fremmer radikalitet ved fjerning av slike lesjoner.

Materiale og metode. Denne oversiktsartikkelen bygger på artikler identifisert ved søk i PubMed med søkeordene «Mohs' surgery» og «basal cell carcinoma», samt på egne erfaringer.
\end{abstract}

Resultater. $10-15 \%$ av alle basalcellekarsinomer har et aggressivt vekstmønster med subkliniske utløpere. Ved Mohs' kirurgi benyttes peroperativ histologisk vurdering av horisontale frysesnitt, noe som innebærer at $100 \%$ av reseksjonsflaten kan vurderes. Hensikten er å redusere risikoen for residiv. Fordi metoden er vevssparende, kan enklere rekonstruksjoner ofte velges. Mohs' kirurgi er ressurskrevende, men med lavere risiko for residiv kan metoden være kostnadseffektiv ved riktig indikasjonsstilling.

Fortolkning. Mohs' kirurgi bør vurderes ved basalcellekarsinom med et aggressivt vekstmønster $\mathrm{i}$ ansiktet.
Ingrid Roscher

ingrid.roscher@ous-hf.no

Seksjon for hudsykdommer

Trine Brevig

Avdeling for patologi

Gro Mørk

Per Helsing

Petter Gjersvik

Seksjon for hudsykdommer

Oslo universitetssykehus, Rikshospitalet

Basalcellekarsinom er den vanligste formen for hudkreft, og insidensen er økende både i Norge og på verdensbasis. Omtrent $10-15 \%$ av disse svulstene har et aggressivt, infiltrerende og/eller skleroserende vekstmønster og kan være vanskelig å avgrense klinisk. De sitter oftest i ansiktet og har mye høyere risiko for residiv enn andre former for basalcellekarsinomer (1).

Mohs' kirurgi er en operasjonsmetode som kan føre til betydelig færre residiver enn andre typer behandling. Ved denne metoden gjøres det peroperative histologiske vurderinger av horisontale frysesnitt, noe som innebærer at hele reseksjonsflaten blir undersøkt - i motsetning til vanlig histologisk undersøkelse, der bare en liten del av reseksjonsflaten undersøkes postoperativt (2).

Vi ønsker med denne artikkelen å gi en kort beskrivelse av Mohs' kirurgi og belyse metodens indikasjoner, fordeler og ulemper.

\section{Materiale og metode}

Artikkelen er basert på relevante forskningsartikler som etter forfatternes vurdering er særlig sentrale, samt på egne kliniske erfaringer med flere enn 90 operasjoner. Vi foretok i november 2010 søk i PubMed med søkeordene «Mohs' surgery» og «basal cell carcinoma» begrenset til «review» og engelskspråklige artikler for perioden 1.1. 1981-1.8. 2010. 131 oversiktsartikler ble identifisert. Vi valgte så ut åtte av disse på grunnlag av en skjønnsmessig vurdering av deres relevans og kvalitet. Artiklene som ikke ble studert nærmere, omhandlet avgrensede emner, slik som særlige lokalisasjoner, pasientgrupper eller kirurgiske og histologiske teknikker. Fra de åtte oversiktartiklene valgte vi ut 37 særlig relevante og hyppig siterte originalartikler.

\section{Epidemiologi}

Antall tilfeller av basalcellekarsinom har vært jevnt økende siden 1970-årene, og basalcellekarsinom er nå den vanligste for- men for kreft. I Sverige registreres det rundt 40000 nye tilfeller i året (3), og man regner med at insidensen er omtrent den samme i Norge. Noen studier tyder på at insidensen øker særlig blant unge voksne $(4,5)$.

Risikofaktorer for utvikling av basalcellekarsinom er lys hud, soleksponering og bruk av solarium.

\section{Kliniske forhold}

Basalcellekarsinom vokser langsomt og metastaserer svært sjelden, men kan vokse lokalt destruerende. Basalcellekarsinomer inndeles etter klinisk morfologi i tre hovedtyper: nodulære, superfisielle og morfealiknende.

Ca. $70 \%$ av alle basalcellekarsinomer er nodulære (6). Slike lesjoner kjennetegnes av en velavgrenset, papuløs eller nodulær lesjon med glinsende overflate og tydelige telangiektasier. Den sentrale delen kan være ulcerert. Slike lesjoner, spesielt de som er lokalisert i ansiktet, kan vokse lokalt destruerende. Superfisielle basalcellekarsinomer utgjør ca. $15 \%$ av alle basalcellekarsinomer (6). De er oftest velavgrensede, lett opphøyde og erytematøse og er vanligvis lokalisert på truncus og ekstremiteter, men kan også forekomme i ansiktet.

De resterende $10-15 \%$ utgjøres av basalcellekarsinomer med et mer aggressivt vekstmønster. I denne gruppen finnes morfealiknende, infiltrerende, mikronodulære og basoskvamøse basalcellekarsinomer (7). Av disse er morfealiknende basalcellekarsinom den vanligste formen. Typisk for et morfealiknende basalcellekarsinom er makuløse eller atrofiske forandringer med gråhvit, eventuelt noe glinsende overflate, økt konsistens ved palpasjon og telangiektasier, som imidlertid kan være lite tydelige. Avgrensningen mot frisk hud er ofte uskarp og vanskelig å bestemme. Lesjonen kan være så lite synlig at den lenge overses av både

\section{Hovedbudskap}

- $10-15 \%$ av basalcellekarsinomer har et lokalt aggressivt vekstmønster og en betydelig risiko for residiv

- Ved Mohs' kirurgi benyttes peroperativ histologisk vurdering av frysesnitt, noe som reduserer risikoen for residiv

- Mohs' kirurgi bør vurderes ved behandling av basalcellekarsinomer i ansiktet med høy risiko for residiv 

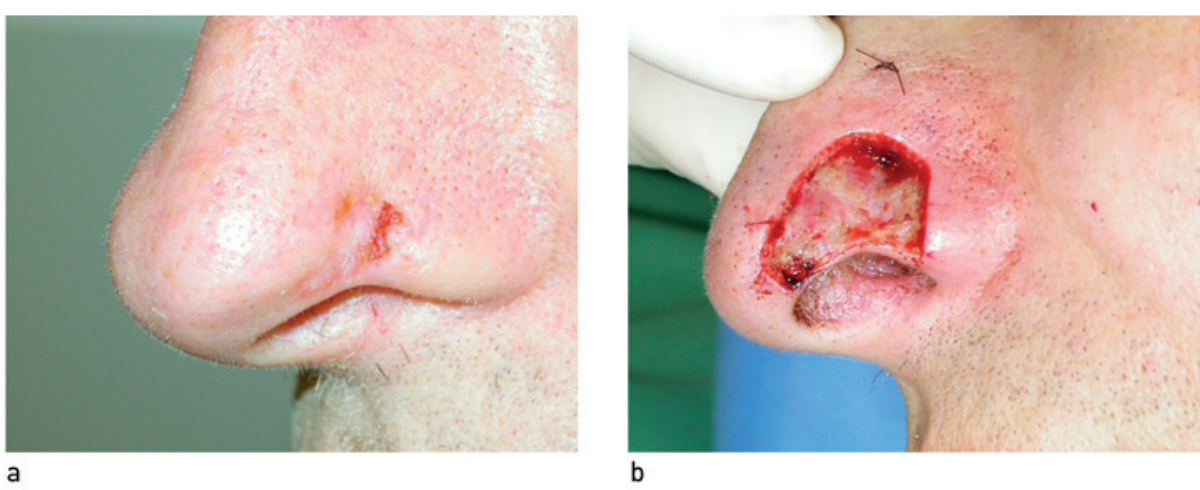

Figur 1 al Morfealiknende basalcellekarsinom på nesevingen før operasjon. b) Samme lesjon etter tre eksisjoner med Mohs' kirurgi

pasient, pårørende og lege eller mistolkes som et arr. Sårdannelse (ulcerasjon) er uvanlig tidlig i forløpet (fig 1).

Nodulære og superfisielle lesjoner har lav risiko for residiv, i motsetning til morfealiknende, infiltrerende, mikronodulære og basoskvamøse basalcellekarsinomer. Disse har et aggressivt vekstmønster og omtales ofte i dermatologisk litteratur som «highrisk basal cell carcinoma» (1). I tillegg bør et ikke-radikalt fjernet basalcellekarsinom og residiv tas med i denne kategorien (8). Et mislykket behandlingsforsøk kan dermed innebære at et basalcellekarsinom med lav risiko for residiv må reklassifiseres til å ha høy risiko for residiv $(9,10)$.

\section{Histologi}

Mens nodulære basalcellekarsinomer som regel er velavgrensede klinisk og histologisk, vokser superfisielle basalcellekarsinomer multifokalt, men begrenset til epidermis, i hvert fall de første årene. Morfealiknende og infiltrerende basalcellekarsinomer, derimot, har et mer uforutsigbart forløp med en vekst som kjennetegnes av til dels lange, klinisk ikke-synlige tumorutløpere i én eller flere retninger (11). Mange basalcellekarsinomer har flere histologiske vekstmønstre i en og samme lesjon (12)

I tillegg til klinisk og histologisk type er tumorstørrelse og lokalisasjon viktige prognostiske faktorer: risiko for residiv øker med økende tumorstørrelse (13) og er høyest ved lokalisasjon sentralt i ansiktet (tab 1) (14).

\section{Behandling}

Nodulære og superfisielle basalcellekarsinomer er vanligvis lette å behandle. Kirurgisk eksisjon med båtsnitt vil i de fleste tilfeller være å foretrekke ved nodulære former, da metoden gir en viss marginkontroll og ofte er den enkleste behandlingen for pasienten. Andre behandlingsmetoder for lesjoner med lav risiko for residiv kan være overflatiske destruktive metoder, slik som kryoterapi og kyrettering, og fotodynamisk terapi, immunmodulerende krem (imiquimod) og strålebehandling (1). Valg av metode er basert på klinisk skjønn der lokalisasjon, tumorstørrelse, histologisk type, pasientens alder og helsetilstand samt preferanser for pasient og lege er av betydning.

Ved behandling av basalcellekarsinom med høy risiko for residiv er det særlig viktig at man får histologisk bekreftet at alt tumorvev er fjernet (15-17). Overflatiske, destruktive metoder bør derfor vanligvis ikke brukes $(1,18)$. Her bør vanlig kirurgisk eksisjon eller Mohs' kirurgi velges. Strålebehandling kan være et godt alternativ til utvalgte pasienter.

\section{Vanlig eksisjon}

med postoperativ marginkontroll

Svulstens kliniske avgrensing identifiseres, og med en passende margin, ofte $2-3 \mathrm{~mm}$, eksideres lesjonen. Resektatet blir så preparert og beskåret på en patologiavdeling, der det blir lagt vertikale tverrsnitt gjennom tumor, slik at avstanden fra tumor til siderendene og

Tabell 1 Risikofaktorer for residiv av basalcellekarsinom

\begin{tabular}{lll} 
& Høy risiko for residiv & Lav risiko for residiv \\
Lokalisasjon & Sentralt i ansikt & $\begin{array}{l}\text { Truncus } \\
\text { Ekstremiteter }\end{array}$ \\
Størrelse & $>10 \mathrm{~mm}$ (ansikt) & $<10 \mathrm{~mm}$ (ansikt) \\
& $>20 \mathrm{~mm}$ (kropp og ekstremiteter) & $<20 \mathrm{~mm}$ (truncus og ekstremiteter) \\
\hline Klinisk utseende & Uskarpt avgrenset & Skarpt avgrenset \\
\hline Histologisk type & $\begin{array}{l}\text { Morfealiknende } \\
\text { Infiltrerende } \\
\text { Mikronodulært } \\
\text { Basoskvamøs }\end{array}$ & $\begin{array}{l}\text { Nodulært } \\
\text { Superfisielt }\end{array}$ \\
& Residiv & \\
Primærsvulst/residiv & Primærsvulst
\end{tabular}

bunnen kan vurderes. Av tverrsnittene skjæres det noen få 2-4 $\mu$ tykke snitt, som vurderes mikroskopisk av patolog. Dermed blir kun en svært liten del av reseksjonsflaten vurdert. Dette er adekvat for undersøkelse av mange svulster i hud, men metoden er ikke god nok når tumor vokser med utløpere som ikke nødvendigvis fanges opp ved slike snitt (fig 2).

Mange slike eksisjoner viser seg å være ikke-radikale, eller de blir vurdert histologisk som radikalt fjernet, men residiverer senere. Dette gjelder spesielt ved morfealiknende og infiltrerende basalcellekarsinomer (19). En viktig årsak til dette kan være at bare en svært liten del av resektatet ble undersøkt histologisk (15).

\section{Mohs' kirurgi}

Den amerikanske kirurgen Fredric Mohs introduserte i 1930-årene en ny metode for eksisjon av maligne hudsvulster. Metoden er senere modifisert flere ganger. Ved Mohs' kirurgi undersøkes peroperative horisontale frysesnitt i stedet for vertikale snitt (fig 3). På denne måten bedømmes hele reseksjonsflaten peroperativt.

Inngrepet starter med at operatøren merker av svulstens kliniske avgrensning og legger til en eksisjonsmargin på 1-2 mm. Nøyaktig merking av lesjonen gjøres med suturer og små incisjoner klokken 3, 6, 9 og 12. Lesjonen eksideres så med $45^{\circ}$ vinkel og med flat bunn. Resektatet fargekodes og prepareres av bioingeniør, slik at hele reseksjonsflaten fremstilles i frysesnitt. En patolog vurderer frysesnittene peroperativt og angir på en tegning hvor det ikke er fritt i reseksjonsflaten. På denne måten kan man forfølge de enkelte tumorutløperne. Operatøren utvider så reseksjonen i det området hvor det er påvist tumorrest. Slik sikrer man at alt tumorvev fjernes, samtidig som man sparer mest mulig friskt vev $(2,7)$.

Radikalitet oppnås vanligvis etter 2-3 eksisjoner (fig 1b) (20). Man ender som regel opp med en mindre huddefekt enn etter vanlig eksisjon - dermed kan man anvende enklere rekonstruksjonsmetoder $(19,21)$. Huddefekten lukkes med primærsutur eller tilheler sekundært. Alternativt anvendes et fullhudstransplantat, lappeplastikk eller kombinasjoner av slike.

Forekomsten av residiv etter Mohs' kirurgi angis i de fleste studier til rundt $1 \%$ ved primære svulster og rundt $5-6 \%$ ved residiv (22-24).

I USA har Mohs' kirurgi vært i økende bruk siden 1970-årene, og ca. en tredel av alle basalcellekarsinomer i USA blir nå behandlet med denne metoden (25). I Europa, der metoden ble tatt i bruk senere, blir en langt mindre andel av basalcellekarsinomer operert med Mohs' kirurgi. Dette innebærer en sterkere seleksjon av lesjoner med høy risiko for residiv og at andelen residiver etter Mohs' kirurgi er noe høyere i europeiske studier enn i amerikanske (26). Ifølge internasjonale retningslinjer skal pasienter med 


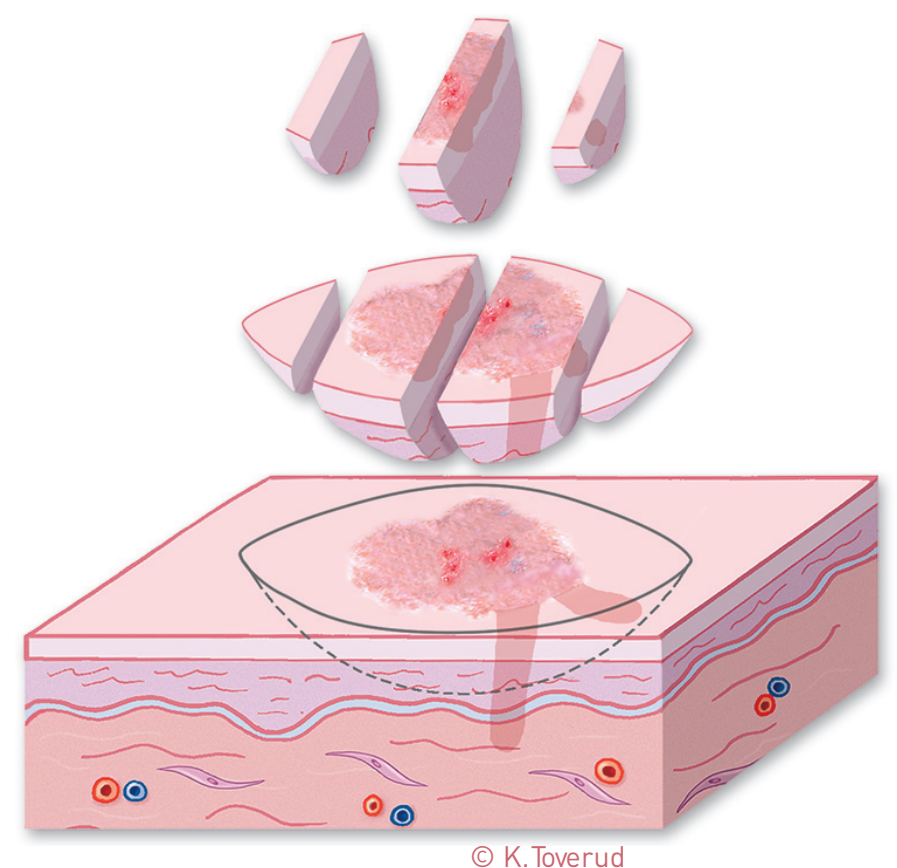

Figur 2 Vanlig båteksisjon som viser ikke-radikalt fjernet tumor, som ikke kommer frem i vertikale uttatte snitt

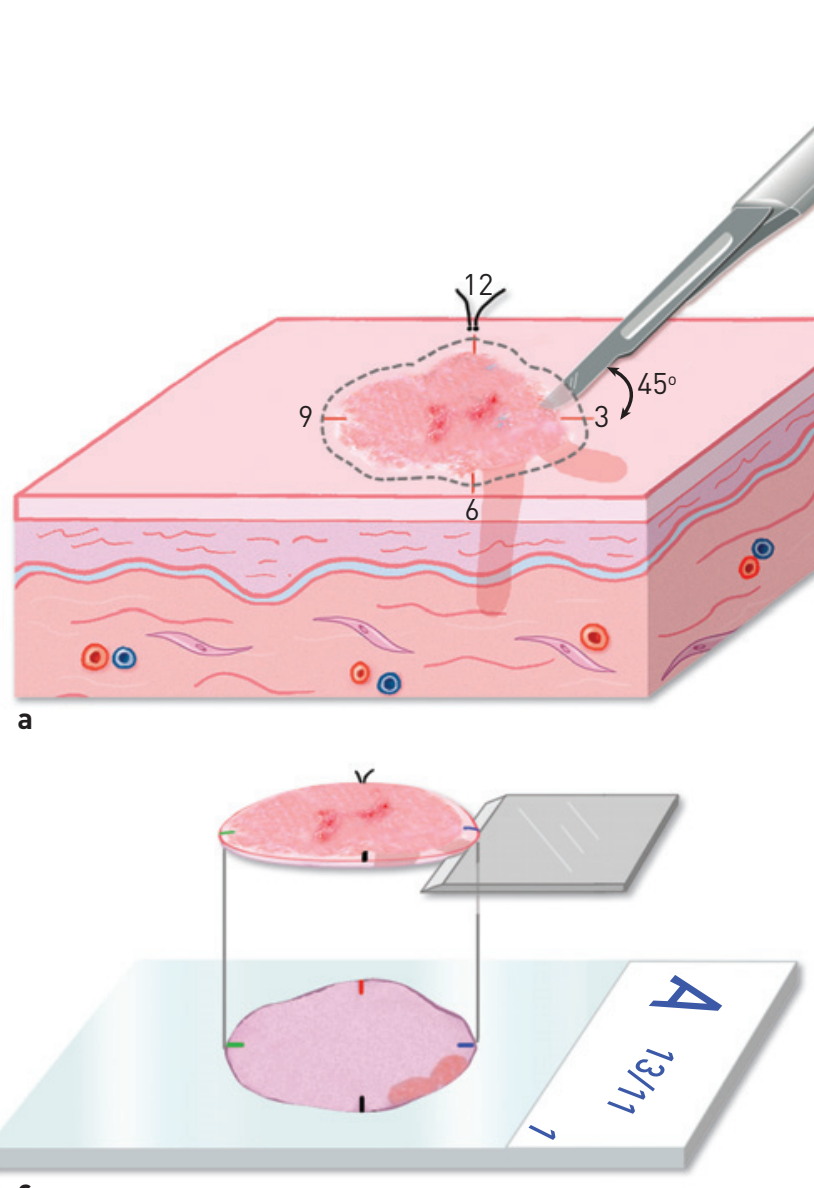

c

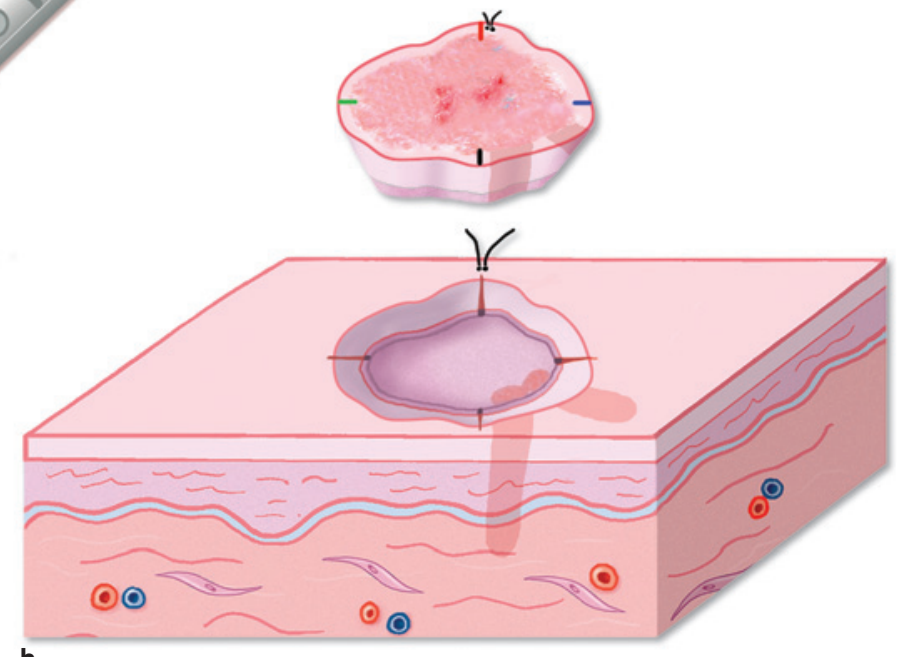

b

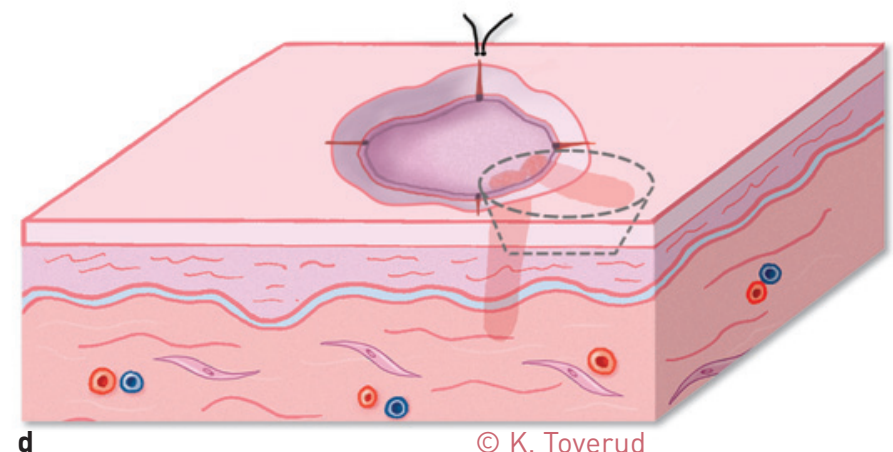

(c) K. Toverud

Figur 3 a) Merket resektat med synlig tumor eksideres med $45^{\circ}$ vinkel og flat bunn. b) Uttatt resektat fargekodes. c) Incisjoner i overflaten gjør at siderendene kan presses ned i samme plan som reseksjonsflaten i bunnen. Horisontale frysesnitt skjæres fra bunnen (100\% av reseksjonsflaten), som vurderes av patolog. d) Reeksisjoner fortsetter til alt tumorvevet er fjernet 
basalcellekarsinom med aggressivt vekstmønster i ansiktet behandles med Mohs' kirurgi $(1,27,28)$.

\section{Alternativer til Mohs' kirurgi}

To andre behandlingsmetoder må nevnes som aktuelle alternativer ved behandling av basalcellekarsinom med høy risiko for residiv $i$ ansiktet.

Ved en totrinns- eller flertrinnsprosedyre foretas vanlig eksisjon og midlertidig dekning av huddefekten med bandasje inntil den histologiske vurderingen av formalinfiksert materiale i parafinsnitt foreligger. Dette gjøres enten med vertikale tverrsnitt eller med mer kompliserte histologiske metoder for undersøkelse av tilnærmet $100 \%$ av reseksjonsflatene $(29,30)$. Lukning av huddefekten gjøres først etter at man har fătt bekreftelse på at alt tumorvev er fjernet. Ulempen med denne prosedyren er at pasienten må gå med et åpent sår inntil histologisvar foreligger, noe som er særlig uheldig hvis det viser seg at man trenger flere eksisjoner.

Overflatisk strålebehandling kan være velegnet hos utvalgte pasienter. Ved primære basalcellekarsinomer angis det en residivrisiko på ca. $7,5 \%$ i to studier, men uten at histologisk type er angitt $(31,32)$. Behandlingen fraksjoneres vanligvis for å oppnå et optimalt kosmetisk resultat.

\section{Diskusjon}

Mohs' kirurgi vurderes i dag som den mest effektive behandlingen for basalcellekarsinom med et aggressivt vekstmønster. Med peroperativ marginkontroll reduseres risiko for resttumorvev og residiv, samtidig som man sparer friskt vev $(19,21,33-35)$. Dette er særlig viktig i ansiktet med tanke på funksjonsbevaring og et best mulig kosmetisk resultat (36).

\section{Færre residiver}

I større pasientserier er residiv etter Mohs' kirurgi rundt $1 \%$ ved primært basalcellekarsinom og rundt 5-6\% ved residivtumor (1). Det er en noe høyere residivfrekvens i europeiske studier enn i amerikanske, noe som kan forklares med et mer begrenset tilbud og seleksjon av de vanskeligste svulstene (26). I pasientserier med vanlig eksisjon er residivraten høyere, rundt 5-10\% ved primærtumor og rundt $15-20 \%$ ved residivtumor. For svulster i sentrale deler av ansiktet er risikoen for residiv etter vanlig eksisjon betydelig høyere (9). Studiene er imidlertid lite sammenliknbare - de varierer mye med henblikk på tumortyper, pasientalder og oppfølgingstid. I den eneste randomiserte studien om Mohs' kirurgi og eksisjon ble det ikke funnet noen sikker forskjell i residivrate (19). Studien er imidlertid blitt kritisert for betydelige metodologiske svakheter (35); blant annet var valg av behandlingsform ikke basert på blindet randomisering alene, og ved vanlig eksisjon ble det ikke foretatt primær lukning, slik det er vanlig å gjøre i Norge.

Det finnes også få studier om effekten av andre behandlingsformer ved basalcellekarsinom med høy risiko for residiv $(22,33)$. Med unntak av stråleterapi er det kontraindisert å behandle basalcellekarsinomer med høy risiko for residiv i ansiktet med destruktive metoder. I en studie publisert i 1977 er det angitt ett residiv etter overflatisk strålebehandling av åtte morfealiknende basalcellekarsinom etter 6-14 år (37).

\section{Vevssparende}

Det er godt dokumentert at jo større marginer man velger, jo mindre er faren for residiv etter vanlig eksisjon (15). Det finnes imidlertid ingen konsensus om adekvate marginer ved vanlig eksisjon - alt fra $2 \mathrm{~mm}$ til 15 $\mathrm{mm}$ er anbefalt $(27,28,38,39)$. Det finnes mange studier der man har forsøkt å definere hva som er adekvate marginer, men $i$ disse studiene er verken svulstene eller pasientene godt nok beskrevet for å kunne trekke sikre konklusjoner. Kun noen få studier omfatter morfealiknende basalcellekarsinomer, og oppfolgingstiden er ofte for kort $(15,22)$.

Store eksisjonsmarginer kan være vanskelig å få til i ansiktet og/eller kan gi lite tilfredsstillende kosmetisk resultat. Ved større huddefekter oppnår man ofte best kosmetisk resultat med lappeplastikk. Dette bør dog ikke benyttes uten sikker marginkontroll, da lappeplastikken kan kamuflere og/ eller flytte eventuelt gjenværende tumorvev. Når residiv erkjennes, må oftest hele rekonstruksjonen fjernes. I tillegg har ofte tumoren fått vokse og destruere et større område enn den ville ha gjort uten kamuflasje. Også under et fullhudstransplantat kan tumor kamufleres over lengre tid.

Ved Mohs' kirurgi unngår man dette. Ved at tumorutløperne forfølges trinnvis, oppnås radikalitet $\mathrm{i}$ tilnærmet alle tilfellene, samtidig som man sparer friskt vev. Huddefekten er som regel mindre enn etter vanlig eksisjon, og enklere rekonstruksjonsløsninger kan velges $(19,21)$.

Ved spesielt store eller dype basalcellekarsinomer med høy risiko for residiv, der kirurgisk inngrep kan bli mutilerende, bør man vurdere overflatisk stråleterapi av kosmetiske hensyn. Det er imidlertid problematisk at det ikke foreligger studier som dokumenterer effekt av slik behandling. Det kosmetiske resultatet etter overflatisk strålebehandling kan bli dårligere over tid. Metoden bør derfor etter vår oppfatning som hovedregel forbeholdes pasienter over 50-60 år $(31,32)$.

\section{Bruk av ressurser}

Mohs' kirurgi er tidkrevende og ressurskrevende. I tillegg til erfaren operatør trengs spesialopplærte bioingeniører og patolog med spesialkompetanse og et laboratorium med kryostat lokalisert nær operasjonsrommet. En studie der man har sammenliknet Mohs' kirurgi med vanlig eksisjon, tyder på at Mohs' kirurgi er en kostnadseffektiv operasjonsmetode ved behandling av residiv (20). For primære basalcellekarsinomer er slike kostnadsanalyser mer usikre. Gode randomiserte studier er ikke gjennomført. Slike studier er nå vanskelig å gjennomføre, ettersom de fleste pasienter vil foretrekke den behandlingen som erfaringsmessig gir best resultat (40). Overflatisk stråleterapi blir av flere forfattere vurdert som en dyr behandling som innebærer mange konsultasjoner, og ofte lang transport på grunn av begrenset stråletilbud (41-43).

Utgiftene til Mohs' kirurgi må også ses i sammenheng med de kostnader som er knyttet til residiv, slik som utgifter til legekontroller, gjentatte biopsitakinger og nye operasjoner $(44,45)$. I tillegg kommer plager og bekymringer for pasienten og risiko for dårlig kosmetisk resultat, særlig etter gjentatte inngrep.

\section{Egne erfaringer}

Mohs' kirurgi ble i februar 2010 etablert ved Hudavdelingen ved Oslo universitetssykehus, Rikshospitalet, i samarbeid med pato$\log$ fra Avdeling for patologi. Vi har til nå behandlet om lag 90 pasienter, med om lag 50 primærsvulster med aggressiv histologisk vekstmønster og størrelse $>1 \mathrm{~cm} \mathrm{i}$ diameter, samt 40 residivsvulster. Indikasjonen stilles av spesialist i hudsykdommer eller plastikkirurgi. Pasienten innkalles til postoperative kontroller etter ett, to og fem år. Så langt er residiv ikke sett. Ved større huddefekter involveres plastikkirurg eller spesialist i øre-nese-hals-sykdommer.

\section{Konklusjon}

Ved basalcellekarsinomer med høy risiko for residiv lokalisert i ansiktet bør behandling med Mohs' kirurgi vurderes. Fordelen er at residivfare reduseres ved peroperativ histologisk vurdering av frysesnitt, og at friskt vev spares.

\section{Ingrid Roscher (f. 1957)}

er spesialist i hudsykdommer og overlege ved Seksjon for hudsykdommer, Oslo universitetssykehus. Hun har fagansvar for ikke-melanom hudkreft.

Ingen oppgitte interessekonflikter.

\section{Trine Brevig}

er spesialist i patologi og overlege ved Avdeling for patologi (dermatopatologi) og Seksjon for hudsykdommer (Mohs' kirurgi-teamet), Oslo universitetssykehus.

Ingen oppgitte interessekonflikter.

\section{Gro Mørk (f. 1965)}

er spesialist i hudsykdommer og overlege ved Seksjon for hudsykdommer ved Oslo universitetssykehus. Hun har dermatokirurgi som særlig interessefelt.

Ingen oppgitte interessekonflikter. 


\section{Per Helsing ( f. 1958)}

er spesialist i hudsykdommer og overlege ved Seksjon for hudsykdommer. Forskningsområder er melanom, hudkreft hos organtransplanterte og hereditært angioødem. Ingen oppgitte interessekonflikter.

\section{Petter Gjersvik (f. 1952)}

er spesialist i hudsykdommer, dr.med. og førsteamanuensis ved Institutt for klinisk medisin, Oslo universitetssykehus, Rikshospitalet. Oppgitte interessekonflikter: Forfatteren har mottatt foredragshonorar fra Pfizer og Abbott og har deltatt på vitenskapelig kongress med utgifter dekket av Abbott, Schering-Plough, LEO Pharma og Galderma.

\section{Litteratur}

1. Telfer NR, Colver GB, Morton CA. Guidelines for the management of basal cell carcinoma. Br J Dermatol 2008. 159: 35-48.

2. Shriner DL, McCoy DK, Goldberg DJ et al. Mohs micrographic surgery. J Am Acad Dermatol 1998; 39: 79-97.

3. Basal cell carcinoma in Sweden 2004-2008. Cancerregistret. www.socialstyrelsen.se (18.2.2011)

4. Leffell DJ, Headington JT, Wong DS et al. Aggressive-growth basal cell carcinoma in young adults. Arch Dermatol 1991: 127: 1663-7.

5. Birch-Johansen F, Jensen A, Mortensen L et al. Trends in the incidence of nonmelanoma skin cancer in Denmark 1978-2007: Rapid incidence increase among young Danish women. Int J Cancer 2010; 127: 2190-8.

6. Scrivener Y, Grosshans E, Cribier B. Variations of basal cell carcinomas according to gender, age, location and histopathological subtype. Br J Dermatol 2002; 147: 41-7.

7. Cumberland L, Dana A Liegeois N Mohs micrographic surgery for the management of nonmelanoma skin cancers. Facial Plast Surg Clin North Am 2009; 17: 325-35.

8. Silverman MK, Kopf AW, Grin CM et al. Recurrence rates of treated basal cell carcinomas. Part 1 : Overview. J Dermatol Surg Oncol 1991; 17: 713-8.

9. McGovern TW, Leffell DJ. Mohs surgery: the informed view. Arch Dermatol 1999; 135: 1255-9.

10. Salasche SJ, Amonette RA. Morpheaform basalcell epitheliomas. A study of subclinical extensions in a series of 51 cases. J Dermatol Surg Oncol 1981; 7: 387-94

11. Batra RS, Kelley LC. Predictors of extensive subclinical spread in nonmelanoma skin cancer treated with Mohs micrographic surgery. Arch Dermatol 2002; 138: 1043-51.

12. Cohen PR, Schulze KE, Nelson BR. Basal cell carcinoma with mixed histology: a possible pathoge- nesis for recurrent skin cancer. Dermatol Surg 2006; 32: 542-51

13. Helsing P, Kramer P, Haugstvedt $\AA$ et al. Kirurgisk behandling av basalcellekarsinomer. Tidsskr Nor Lægeforen 2004: 124: 2740-2.

14. Miller SJ. Biology of basal cell carcinoma (Part I). J Am Acad Dermatol 1991; 24: 1-13.

15. Gulleth Y, Goldberg N, Silverman RP et al. What is the best surgical margin for a Basal cell carcinoma: a meta-analysis of the literature. Plast Reconstr Surg 2010; 126: 1222-31.

16. Leibovitch I, Huilgol SC, Selva D et al. Basal cell carcinoma treated with Mohs surgery in Australia I. Experience over 10 years. J Am Acad Dermatol 2005; 53: 445-51.

17. Nagore E, Grau C, Molinero J et al. Positive margins in basal cell carcinoma: relationship to clinical features and recurrence risk. A retrospective study of 248 patients. J Eur Acad Dermatol Venereol 2003; 17: 167-70.

18. Wagner RF Jr, Cottel WI. Multifocal recurrent basal cell carcinoma following primary tumor treatment by electrodesiccation and curettage. J Am Acad Dermatol 1987: 17: 1047-9.

19. Smeets NW, Krekels GA, Ostertag JU et al. Surgical excision vs Mohs' micrographic surgery for basal-cell carcinoma of the face: randomised controlled trial. Lancet 2004: 364: 1766-72.

20. Mosterd K, Krekels GA, Nieman FH et al. Surgical excision versus Mohs' micrographic surgery for primary and recurrent basal-cell carcinoma of the face: a prospective randomised controlled trial with 5-years' follow-up. Lancet Oncol 2008; 9 : $1149-56$

21. Muller FM, Dawe RS, Moseley H et al. Randomized comparison of Mohs micrographic surgery and surgical excision for small nodular basal cell carcinoma: tissue-sparing outcome. Dermatol Surg 2009; 35: 1349-54

22. Thissen MR, Neumann MH, Schouten LJ. A systematic review of treatment modalities for primary basal cell carcinomas. Arch Dermatol 1999; 135: 1177-83

23. Rowe DE, Carroll RJ, Day CL jr. Long-term recurrence rates in previously untreated (primary) basa cell carcinoma: implications for patient follow-up. J Dermatol Surg Oncol 1989; 15: 315-28.

24. Rowe DE, Carroll RJ, Day CL jr. Mohs surgery is the treatment of choice for recurrent (previously treated) basal cell carcinoma. J Dermatol Surg Oncol 1989; 15: 424-31.

25. Smeets NW, Kuijpers DI, Nelemans P et al. Mohs micrographic surgery for treatment of basal cell carcinoma of the face-results of a retrospective study and review of the literature. Br J Dermatol 2004; 151: $141-7$

26. Wennberg AM, Larkö O, Stenquist B. Five-year results of Mohs' micrographic surgery for aggres sive facial basal cell carcinoma in Sweden. Acta Derm Venereol 1999: 79: 370-2.

27. Sterry W; European Dermatology Forum Guideline Committee. Guidelines: the management of basal cell carcinoma. Eur J Dermatol 2006; 16: 467-75.

28. Dandurand M, Petit T, Martel P et al. Managemen of basal cell carcinoma in adults Clinical practice guidelines. Eur J Dermatol 2006; 16: 394-401

29. Rapini RP. Comparison of methods for checking surgical margins. J Am Acad Dermatol 1990: 23. 288-94.

30. Wetzig T, Woitek M, Eichhorn K et al. Surgical excision of basal cell carcinoma with complete margin control: outcome at 5-year follow-up. Dermatology 2010; 220: 363-9.

31. Avril MF, Auperin A, Margulis A et al. Basal cell carcinoma of the face: surgery or radiotherapy? Results of a randomized study. Br J Cancer 1997; 76: $100-6$.

32. Silverman MK, Kopf AW, Gladstein $\mathrm{AH}$ et al. Recurrence rates of treated basal cell carcinomas. Part 4: X-ray therapy. J Dermatol Surg Oncol 1992; 18 549-54.

33. Bath-Hextall FJ, Perkins W, Bong J et al. Interventions for basal cell carcinoma of the skin. Cochrane Database Syst Rev 2007; 24: CD003412.

34. Perkins W. Who should have Mohs micrographic surgery? Curr Opin Otolaryngol Head Neck Surg 2010; 18: 283-9.

35. Otley CC. Mohs' micrographic surgery for basalcell carcinoma of the face. Lancet 2005; 365: 1226-7, author reply 1227

36. Roenigk RK, Roenigk HH Jr. Current surgical management of skin cancer in dermatology. J Dermatol Surg Oncol 1990; 16: 136-51.

37. Bart RS, Kopf AW, Gladstein AH. Treatment of morphea-type basal cell carcinomas with radiation therapy. Arch Dermatol 1977; 113: 783-6.

38. Lalloo MT, Sood S. Head and neck basal cell carcinoma: treatment using a 2-mm clinical excision margin. Clin Otolaryngol Allied Sci 2000; 25: 370-3.

39. Wolf DJ, Zitelli JA. Surgical margins for basal cell carcinoma. Arch Dermatol 1987; 123: 340-4.

40. Feldman S, Pearce DJ, Williford PM. Surgical decision making for basal-cell carcinoma of the face. Lancet Oncol 2008; 9: 1119-20.

41. Ho T, Byrne PJ. Evaluation and initial management of the patient with facial skin cancer. Facial Plast Surg Clin North Am 2009; 17: $301-7$

42. Neville JA, Welch E, Leffell DJ. Management of nonmelanoma skin cancer in 2007. Nat Clin Pract Oncol 2007; 4: 462-9.

43. Motley RJ, Gould DJ, Douglas WS et al. Treatmen of basal cell carcinoma by dermatologists in the United Kingdom. Br J Dermatol 1995; 132: 437-40.

44. Cook J, Zitelli JA. Mohs micrographic surgery: a cost analysis. J Am Acad Dermatol 1998; 39: 698-703.

45. Tierney EP, Hanke CW. Cost effectiveness of Mohs micrographic surgery: review of the literature. J Drugs Dermatol 2009; 8: 914-22.

Mottatt 15.3. 2011, første revisjon innsendt 30.6. 2011, godkjent 6.10. 2011. Medisinsk redaktør Jon Amund Kyte. 